university and they must have passed approved examinations in botany, geology, physics and chemistry if these have not been taken in the degree courses. The reason for this change, and the concurrent change in the curriculum of the School, is found in the requirements of the forest services and the development of forestry in the Empire. It has been decided also that after August of this year the Imperial Forestry Institute, established in 1924 and controlled by a director other than the professor of forestry since 1936 , is to be joined to the professor's department as a self-contained unit under the immediate charge of the professor. Between 1920 and 1938, 324 men have been trained in the School of Forestry, 258 of whom have passed into the various forest services. During the fifteen years of the independent existence of the Institute, there have been 350 students in attendance.

\section{International Bibliography of Agricultural Economics}

Tue International Institute of Agriculture at Rome has just issued the first number of a new quarterly publication-the International Bibliography of Agricultural Economics-compiled under tho technical direction of the librarian, Dr. S. von Frauendorfer. The neod for a bibliography of this nature was realized in 1932 , and since 1933 twolvo publications on these lines have appeared in the journal Berichte über Landwirtschaft (Parey, Berlin). The thirteenth issue, giving tho literature up to June I, 1938, will bo found in tho Berichte as usual, but subsequent publications are given in the new volume. The International Bibliography of Agricultural Economics covers the economic and social aspects of agriculture, such as agricultural economics, agricultural policy, settlement, credit, co-operation, insurance, marketing, prices, statistics, farm organization and management, valuation, labour, accounting, rural sociology, agricultural history and geography, legislation and education and all other agricultural problems, in so far as they aro considered from the economic and social point of view. Only publications of purely technical character are excluded. Titles of all publications, whether books, bulletins, pamphlets or articles in periodicals, are indicated, including all bibliographical details required for proper identification. All langunges receive equal treatment, and titles in the less linown languages are provided with a translation. The bibliography, which is the only one covering systematically the world literature on agricultural economics, is carefully classified by subjects. An author index will be supplied at the end of each volume. The annual subscription, postage included, is $6 s$. $6 d$.

\section{Seale-Hayne Agricultural College}

TuE criticism is frequently made that the investigations of colleges and research institutes are not reported to the farmer in a form that can be easily understood. To meet this need, and at the same time to make the work of the College more widely known, Seale-Hayne Agricultural College, Nexton Abbot, Devon, is issuing an annual in which it is hoped to deal with a wide variety of subjects in a manner likely to prove of real value to the practical man. The first number has just been published. It contains articles on the chemical composition of broccoli, potato eelworm, varieties of winter oat, and on the animal husbandry side, efficiency factors in the production of bacon pigs, milk production costs and the building up of a tuberculosis-free dairy herd. A list of investiga. tions in progress at the College and of pamphlets already published is appended. Though of particular value to farmers and growers in the south-west of England, the volume will no doubt bo also of interest to agriculturists in other districts.

\section{The John Innes Horticultural Institution}

Tin John Innes Horticultural Institution is unique in Great Britain in combining research in genetics, cytology and biochemistry with pomology and horticulture. The twenty-ninth annual report contains the results of the investigations during the year 1937-38. Two interesting discoveries in cytology were that the chiasmata in the megasporocytes were less randomly distributed than in the microsporocytes of Lilium testacum and that the centromere could divide sometimes transversely as well as longitudinally. The genetical analysis of Tropaeolum, Streptocarpus, Verbena, Zea, Lotus and Primula sinensis is pro. ceeding. There are two linkage groups of most of the identified colour genes in Streptocarpus; both groups oxhibit tight linkage between the genes. 16 genes of Verbena may bo assorted into five linkage groups. The investigation of Rubus species has shown that different varieties, usually polyploid, may be (1) sexual, (2) apomictic, or (3) partly sexual and partly apomictic in reproduction. Even the apomictic varieties can segregate, thus indicating that the first division of meiosis occurs in these forms. The Bio. chemistry Department has been investigating several interesting now plant pigments such as dunnione in Streptocarpus Dunnii and anthocyanins from ferns and unusual sap-soluble substances in Celosia. The training of gardeners and the investigation of suitable soil composts again met with success and good uso was made of the provision of research facilities for visitors.

\section{Bibliography of Seismology}

WE have recently received vol. 12, No. 19 (July, August and September 1938) of the Bibliography of Seismology, published by the Dominion Observatory at Ottaws. This time 117 works are listed and there aro twenty-six collaborators representing 12 countries. It contoins references among many notable works to Dr. C. Davison's "Studies on the Periodicity of Earthquakes" and works by Gutenberg and Richter, Lynch, and Bullen all bearing on the problem of the earth's central core. Particularly interesting is the notice of the article on Frank Lloyd Wright from Readers Digest, directing attention to the importance of the design of buildings in earthquake-troubled countries. Wright designed tho Imperial Hotel in Tokyo to withstand earthquake shocks, and it has done so. 